Jurnal Akuntansi dan Investasi, Vol. 17 No. 2, Hlm: 141-157, Juli 2016

Artikel ini tersedia di website: http://journal.umy.ac.id/index.php/ai

DOI: 10.18196/jai.2016.0051.141-157

\title{
Pendekatan Hot-Fit Framework dalam Generalized Structural Component Analysis pada Sistem Informasi Manajemen Barang Milik Daerah: Sebuah Pengujian Efek Resiprokal
}

Shofana Erimalata

Program Magister Akuntansi, Universitas Mataram, Jl. Majapahit No. 62. Gomong, Mataram, NTB, Indonesia

\begin{tabular}{l} 
A R T I C L E I N F O \\
\hline Article history: \\
received 29 Mar 2015 \\
revised 8 Apr 2016 \\
accepted 16 Apr 2016
\end{tabular}

Keywords:

Accrual Basis; Fixed

Assets; GeSCA;

HOT-Fit Framework; SIMDA BMD;

Information Quality

\begin{abstract}
A B S T RACT
This study aims to examines the determinant of the information quality of fixed assets on the accrual-based balance sheet using HOT-Fit Framework approach with Generalized Structural Component Analysis (GeSCA) method. The study using questionnaire with 90 respondents who represented all the local government agencies of Mataram City Government. Data anaylisis employs Structural Equation Model (SEM). The study reveals there is a reciprocal relation between organizational controling and the information quality of fixed assets. The study also indicates that the software quality of Sistem Informasi Manajemen Barang Milik Daerah/Management Information System for Local Government's Goods (SIMDA BMD) affecting the user satisfaction and organizational controling. The implications of these results can be used as consideration in adjusting the Mataram City Government accounting policy regarding fixed assets administration in order to produce quality information on fixed assets for the local government accrual-based balance sheet. Then, users of information system are needs to trained in order to increase competence to conduct the administration of fixed assets accrual based, so it can contribute to improve the quality of fixed asset information presented on the accrual based balance sheet.
\end{abstract}

\section{PENDAHULUAN}

Laporan keuangan Pemerintah Daerah (Pemda) di Indonesia, khususnya di provinsi Nusa Tenggara Barat (NTB) saat ini memasuki masa peningkatan kualitas. Hal ini ditandai dengan meningkatnya jumlah Laporan Keuangan Pemerintah Daerah (LKPD) yang memperoleh opini Wajar Tanpa Pengecualian (WTP) dari Badan Pemeriksa Keuangan Republik Indonesia (BPK RI). Peningkatan opini BPK juga diperoleh LKPD Kota Mataram untuk Tahun Anggaran 2014. Bagi Pemerintah Kota Mataram, memperoleh opini WTP (Ikhtisar Hasil Pemeriksaan BPK RI, 2014) untuk pertama kalinya merupakan sebuah prestasi yang membanggakan, setelah bertahun-tahun selalu mendapat opini Wajar Dengan Pengecualian (berturut-turut sejak 2006). Keberhasilan ini tentunya menjadi tantangan bagi Pemerintah Kota Mataram untuk terus mempertahankannya. Salah satu upaya yang akan dilakukan adalah meningkatkan sistem manajemen aset yang akan mendukung optimalisasi pengelolaan dan pelaporan keuangan daerah.
Sebagaimana diamanatkan dalam Peraturan Pemerintah (PP) Nomor 71 Tahun 2010 tentang Standar Akuntansi Pemerintah (SAP) dan Peraturan Menteri Dalam Negeri (Permendagri) Nomor 64 Tahun 2013 tentang Penerapan SAP Berbasis Akrual pada Pemerintah Daerah, Pemda diwajibkan untuk menerapkan penyajian laporan keuangan berbasis akrual (akrual penuh) paling lambat tahun anggaran 2015. Dengan demikian seharusnya tahun 2015 semua Pemda sudah melaksanakan akuntansi berbasis akrual yang dalam penyajiannya termasuk melakukan restatement (penyajian kembali) di dalamnya. Hal ini juga diperkuat secara legal formal pada pasal 9 Permendagri Nomor 64 Tahun 2013 agar Pemda menyajikan kembali Laporan Realisasi Anggaran, Neraca dan Laporan Arus Kas tahun sebelumnya pada tahun pertama penerapan SAP berbasis akrual.

Restatement merupakan perlakuan akuntansi yang dilakukan atas pos-pos dalam neraca yang perlu disajikan kembali pada awal periode ketika pemerintah daerah untuk pertamakali akan mengimplementasikan kebijakan akuntansi yang baru dari semula basis kas menuju akrual (cash towards 
aсcrual) menuju basis akrual (aсcrua). Berdasarkan Peraturan Walikota No 13/2014 tentang Kebijakan Akuntansi Pemerintah Kota Mataram, maka salah satu akun dalam neraca yang perlu dilakukan restatement adalah akun aset tetap. Nilai akun aset tetap perlu untuk dilakukan penyajian kembali karena pada periode sebelumnya (2014) nilai aset tetap belum menerapkan kebijakan akuntansi berbasis akrual, yaitu belum mengurangi nilai buku dengan akumulasi penyusutan aset. Aset tetap merupakan pos neraca yang jumlahnya paling besar dalam neraca Kota Mataram, sehingga salah saji dalam akun aset tetap akan berpengaruh secara material dalam pemeriksaan oleh BPK. Kriteria materialitas ini menjadi salah satu tantangan dalam upaya mempertahankan opini WTP yang telah diperoleh.

Tekanan regulasi untuk melakukan penghitungan akumulasi penyusutan masing-masing aset, kemudian melakukan penyajian kembali dalam neraca, tidak akan menjadi hal yang sulit apabila telah tersedia data aset yang andal dan relevan. Data aset tersebut akan dijadikan dasar pengakuan akun aset tetap dalam kegiatan restatement. Permasalahan yang terjadi di Kota Mataram adalah data-base aset tetap dianggap belum dapat menyuguhkan data yang andal dan relevan. Hal ini dikarenakan beberapa aset di Kota Mataram masih terkendala masalah status penguasaan dan legalitasnya sehingga berpengaruh pada penyelesaian penilaian aset tetap yang dimiliki (Nurdiana, 2015). Dalam penelitian Atikah et al. (2015) ditemukan bahwa kendala yang dialami oleh Pemerintah Kota Mataram dalam melakukan pengelolaan aset tetap adalah karena penatausahaan melalui Sistem Informasi Manajemen Barang Milik Daerah (SIMDA BMD), kapasitas sumber daya manusia (SDM), dan pengendalian organisasi yang dimiliki dalam pengelolaan aset belum memadai dalam menghadapi tantangan penerapan Sistem Akuntansi Pemerintahan (SAP) berbasis akrual. Hal ini terlihat dari masih ada aset tetap yang dicatat di Kartu Inventaris Barang (KIB) dengan dinilai Rp 1,saja karena kesulitan mencantumkan berapa nilai wajar saat perolehan aset. Penyebab lain karena masih minimnya pengetahuan para pengurus barang mengenai: sistem akuntansi berbasis akrual, perlakuan kapitalisasi terhadap biaya-biaya yang sebenarnya menambah nilai dan masa manfaat aset tetap, pentingnya kelengkapan dokumen untuk pengakuan suatu aset tetap, kesesuaian data aset pada data-base dan kondisi fisik di lapangan, serta pentingnya rekonsiliasi aset dari masing-masing Satuan Kerja Perangkat Daerah (SKPD).

Penelitian Padmowati (2004), Laksono (2015), (Komara, 2006), Sudarmadi (2010), Santoso (2012) dan Putra dan ALfian (2016) mengemukakan bahwa kesuksesan penerapan teknologi informasi harus diukur secara komprehensif dengan mengikutsertakan keterlibatan organisasi dalam pemanfaatan teknologi informasi oleh pengguna. Untuk melakukan pengukuran keberhasilan suatu sistem informasi yang lebih komprehensif dalam memberikan manfaat bagi suatu organisasi maka Yusof et al. (2006) memperkenalkan sebuah model bernama Human-Organization-Technology (HOT)-Fit Framework untuk melakukan evaluasi sistem informasi secara komprehensif.

Model (HOT)-Fit Framework menggabungkan D \& M IS Success Model dengan IT-Organization Fit Model, menghasilkan framework yang menempatkan komponen penting dalam sistem informasi, yaitu: Manusia (Human), Organisasi (Organization) dan Teknologi (Technology), dengan kesesuaian hubungan di antara tiga kompenen tersebut. Penelitian Mohamadali dan Garibaldi (2012) mengemukakan pentingnya penggunaan konsep "fit" dalam melihat hubungan Manusia (Human), Organisasi (Organization) dan Teknologi (Technology). Hingga saat ini (HOT)-Fit Framework belum banyak digunakan untuk mengukur kesuksesan sistem informasi yang digunakan dalam kegiatan pemerintah daerah, namun lebih banyak digunakan untuk mengukur kesuksesan sistem informasi rumah sakit dan sistem informasi universitas, seperti penelitian Poluan et al. (2014), Nasir dan Syaputra (2014), Diana (2014) dan Krisbiantoro et al. (2015). Sementara, penelitian dengan model (HOT)-Fit Framework untuk lembaga pemerintahan dilakukan oleh Penelitian Yusof dan Yusuff (2013) dan Bahrawi (2013).

Pada konteks penelitian ini, pengukuran kesuksesan SIMDA BMD secara lebih komprehensif dengan menggunakan (HOT)-Fit Framework ini dimotivasi oleh Laporan Hasil Pemeriksaan Kinerja Pemerintah Kota Mataram oleh BPK RI Perwakilan NTB atas efektivitas upaya pemerintah daerah dalam implementasi SAP berbasis akrual pada tahun 2014 sampai dengan triwulan III tahun 2015. Berdasarkan hasil pemeriksaan diketahui bahwa pada Pemerintah Kota Mataram masih terdapat hal-hal yang belum memadai terkait dukungan regulasi dan komitmen pimpinan, kompetensi SDM pengelola keuangan, aset dan teknologi informasi, optimalisasi pemanfaatan teknologi informasi dan ketersediaan database. Penelitian ini merupakan pengembangan dari penelitian Krisbiantoro et al. (2015) serta penelitian Surastiani dan Handayani (2015). Penelitian ini akan mengelaborasi penggunaan (HOT)-Fit Framework untuk mengukur kesuksesan aplikasi SIMDA BMD dengan lebih komprehensif dari sisi pengguna dan pengendalian organisasi yang diberikan, yang dalam penelitian-penelitian sebelumnya, pengukuran kesuk- 
sesan sistem informasi hanya dilakukan dari perspektif sistem dan pengguna sistem saja.

Penelitian ini mengekplorasi beberapa kebaruan, pertama melakukan pengukuran kesuksesan sistem informasi yang lebih komprehensif dengan menggunakan (HOT)-Fit Framework. Penelitian ini menguji kesesuaian aplikasi SIMDA BMD (technology), kepuasan pengguna (human) dan pengendalian organisasi (organization) dalam menghasilkan informasi aset tetap yang berkualitas. Kedua, dalam penelitian ini variabel kualitas pelayanan bukan merupakan dimensi pengukur sistem seperti yang digunakan dalam penelitian-penelitian sebelumnya, yakni Yusof et al. (2006; 2008), tetapi merupakan bagian dari pengendalian layanan yang diberikan oleh organisasi, karena sifat dari SIMDA BMD sebagai mandatory system pada lingkup Pemerintah Kota Mataram. Ketiga, penelitian ini juga akan melihat hubungan reciprocal antara pengendalian organisasi dan kualitas informasi aset tetap yang dihasilkan SIMDA BMD serta hubungan reciprocal antara kepuasan pengguna dan kualitas informasi aset tetap yang dihasilkan SIMDA BMD sebagai bukti empiris bahwa antara organization dan net benefits serta antara human dan net benefits terdapat hubungan dua arah (Yusof et al., 2006). Model penelitian ini menggunakan metode Generalized Structural Component Analysis (GeSCA) karena penggunaan model struktural berbasis komponen ini mampu merefleksikan variabel-variabel laten dalam bentuk dimensi yang direfleksikan berbagai indikator, serta mampu menganalisis hubungan timbal balik (reciproca) diantara variabel laten.

\section{TINJAUAN LITERATUR DAN PERUMUSAN HIPOTESIS}

Aspek akuntansi pada pemerintah daerah tidak hanya terbatas pada pembukuan saja, melainkan juga meliputi aspek penatausahaan. Penatausahaan sendiri adalah rangkaian kegiatan yang meliputi pembukuan, inventarisasi dan pelaporan barang milik daerah sesuai dengan ketentuan yang berlaku (PP No. 27 tahun 2014 dan Permendagri No. 17 Tahun 2007). Pelaporan Barang Milik Daerah disusun menurut perkiraan neraca yang terdiri dari aset lancar, aset tetap dan aset lainnya (PP No. 27 tahun 2014). Laporan Barang Milik Daerah (BMD) yang disusun pengelola barang milik daerah digunakan sebagai bahan untuk menyusun neraca Pemerintah Daerah (PP 27/2014 pasal 88 avat 3, Permendagri 17/2007 pasal 29 ayat 1, Peraturan Daerah (Perda) Kota Mataram No. 17 Tahun 2011 pasal 97). Dari definisi tersebut, dapat disimpulkan bahwa nilai aset tetap yang disajikan dalam neraca adalah merupakan representasi dari penatausahaan barang milik daerah yang dilakukan Pemda.

Sejak tahun 2011, seluruh pencatatan, pemindahan dan penghapusan aset tetap daerah Kota mataram dilakukan menggunakan sistem informasi berbasis komputer, yaitu Sistem Informasi Manajemen Barang Milik Daerah (SIMDA BMD). Dasar hukum kewajiban menggunakan SIMDA BMD dalam pengelolaan aset tetap daerah diatur dalam pasal 98 Perda Kota Mataram No. 17/2011 tentang Pengelolaan Barang Milik Daerah. Kesuksesan SIMDA BMD akan sangat dibutuhkan dalam menghasilkan informasi aset tetap daerah yang andal dan relevan, sebagai alah satu cara untuk menjawab tantangan implementasi restatement pada tahun pertama penerapan SAP basis akrual. Informasi nilai aset tetap dari output SIMDA BMD akan dijadikan dasar pengakuan akun aset tetap yang akan disajikan kembali dalam neraca yang disesuaikan dengan kebijakan akuntansi berbasis akrual.

\section{Human-Organizational-Technology (HOT) Fit Framework}

Yusof et al. (2006) memberikan suatu kerangka baru yang dapat digunakan untuk melakukan evaluasi sistem informasi yang disebut Human-OrganizationTechnology (HOT) Fit Framework. " This framework builds on the IS Success Model and IT-Organization Fit Model. HOT-fit addresses the essential components of IS, namely human, organization and technology and the fit between them" (Yusof et al., 2006). Model ini menempatkan komponen penting dalam sistem informasi yakni Manusia (Human), Organisasi (Organization) dan Teknologi (Technology) dan kesesuaian hubungan diantaranya. HOT-Fit Framework awalnya dikembangkan dari penggabungan IS Success Model (DeLone dan McLean, 2003) dan ITOrganization Fit Model yang dikemukakan oleh Scott-Morton (1991 dalam Yusof et al., 2006) sebagai rerangka untuk mengevaluasi Health Information System (HIS). IS Success Model digunakan untuk mengidentifikasi faktor, dimensi dan indikator pengukuran, sedangkan IT-Organization Fit Model mengidentifikasikan hubungan dan kesesuaian konsep diantara faktor manusia, teknologi dan organisasi.

Model ini pada penelitian Yusof dan Yusuff (2013) digunakan untuk mengukur penerapan sistem informasi pada sektor publik, yaitu mengukur kesuksesan e-government Pemerintah Malaysia yang disebut Project Monitoring System (PMS). Yusof dan Yusuff (2013) mengemukakan bahwa faktor manusia, teknologi dan organisasi merupakan komponen penting dalam penerapan sistem informasi, dimana 


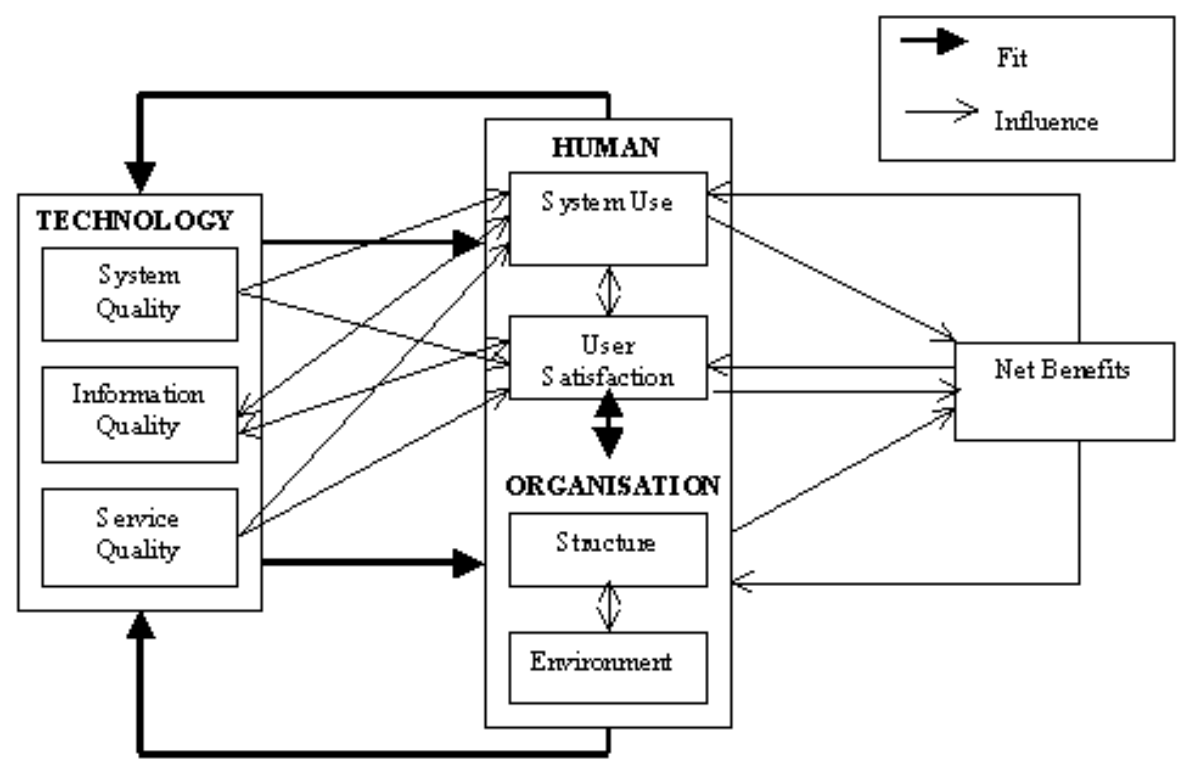

Gambar 1. Human-Organizational-Technology (HOT) Fit Framework Sumber: Yusof (2011)

dampak sistem dievaluasi melalui keuntungan bersih (net benefits) secara keseluruhan.

Pada Gambar 1 terlihat bahwa HOT-Fit Framework terdiri atas beberapa hubungan timbal balik (reciprocal) sebagaiana yang dijelaskan Yusof et al. (2006) sebagai berikut:

"Some of these relationships are two ways:

....

System Use and User Satisfaction are direct antecedents of Net Benefits. Net Benefits subsequently affect System Use and User Satisfaction. Similarly, Organizational Structure and Environment are direct antecedents of Net Benefits. Net Benefits subsequently have impact on organizational Structure and Environment”.

Menurut Yusof et al. (2006) faktor-faktor yang membentuk HOT-Fit Framework adalah sebagai berikut:

\section{(1) Manusia (Human)}

Komponen manusia menilai sistem informasi dari sisi penggunaan sistem (system use) pada frekwensi dan luasnya fungsi dan penyelidikan sistem informasi. System use juga berhubungan dengan siapa yang menggunakan (who use it), tingkat penggunanya (level of user), pelatihan, pengetahuan, harapan dan sikap menerima (acceptance) atau menolak (resistance) sistem. Komponen ini juga menilai sistem dari aspek kepuasan pengguna yaitu keseluruhan evaluasi dari pengalaman pengguna dalam menggunakan sistem informasi dan dampak potensial yang dirasakan dari penggunaan sistem informasi. Kepuasan pengguna dapat dihubungkan dengan persepsi manfaat dan sikap pengguna terhadap sistem informasi yang dipengaruhi oleh karakteristik personal.

\section{(2) Organisasi (Organization)}

Komponen Organisasi (organization) menilai sistem dari aspek struktur organisasi dan lingkungan organisasi tempat sistem teknologi informasi diimplementasikan. Struktur organisasi terdiri dari tipe, budaya, politik, hirarki, perencanaan dan pengendalian sistem, strategi, manajemen dan komunikasi. Kepemimpinan, dukungan dari top manajemen dan dukungan staf merupakan bagian yang penting dalam mengukur keberhasilan sistem. Sedangkan lingkungan organisasi terdiri dari sumber pembiayaan, pemerintahan, politik, kompetisi, hubungan interorganisasional dan komunikasi.

(3) Teknologi (Technology)

a) Kualitas Sistem

Faktor ini digunakan untuk mengukur kualitas sistem teknologi informasinya sendiri. Beberapa indikator yang pernah diteliti Yusof et al. (2006) dan Yusof et al. (2008) untuk mengukur nilai dari kualitas sistem adalah sebagai berikut:

- indikator kemudahan yang meliputi: mudah digunakan (ease of use) dan mudah dipelajari (ease of learning),

- indikator efisiensi yang meliputi: lama respon (response time) dan lama loading,

- indikator kehandalan sistem yang meliputi: terdapat bantuan teknis sistem (access to technical support), adanya peringatan kesala- 
han, fleksibel jika diintegrasikan dengan sistem lain (availability), teruji bebas dari eror (reliability) dan keamanan sistem (security),

- indikator kelengkapan meliputi: fitur-fitur yang lengkap, dan isi data-base yang lengkap.

b) Kualitas Informasi (Output)

Faktor ini digunakan untuk mengukur kualitas keluaran (output) dari sistem informasi. Beberapa indikator yang pernah diteliti Yusof et al. (2006) dan Yusof et al. (2008) untuk mengukur nilai dari kualitas informasi output adalah sebagai berikut:

- Indikator isi (content) yang meliputi: format sesuai kebutuhan, bentuk serta relevansi dari informasi yang dihasilkan, kelengkapan (completeness),

- Indikator kegunaan (usefulness) yang meliputi: mudah dibaca, ringkas dan padat, informatif, penting,

- Tingkat kehandalan data: akurasi data, ketepatwaktuan, dapat dibandingkan dan dapat diverifikasi.

c) Kualitas Pelayanan

Kualitas layanan berfokus pada keseluruhan dukungan yang diterima dari penyedia jasa layanan sistem. Kualitas layanan dapat dinilai dengan kecepatan respon, jaminan, empati, dukungan teknis dan tindak lanjut layanan kepada pengguna sistem.

d) Manfaat bersih

Merupakan manfaat yang diperoleh dari penggunaan sistem. Net benefits dapat diukur dari manfaat sistem secara langsung (misalnya dari informasi yang dihasilkan sistem) maupun dari manfaat secara tidak langsung seperti dampak pada kinerja, efisiensi dan efektifitas kegiatan organisasi.

\section{Pengendalian Organisasi}

Pengendalian pada organisasi sektor publik dilakukan dengan sistem pengendalian internal. Sistem pengendalian internal meliputi struktur organisasi, metode, dan ukuran-ukuran yang dikoordinasikan untuk menjaga kekayaan organisasi, mengecek ketelitian dan keandalan data akuntansi, mendorong efisiensi, dan dipatuhinya kebijakan pimpinan (Bastian, 2011). Berdasarkan tujuan sistem pengendalian internal tersebut maka pengendalian internal organisasi dibagi menjadi dua, yaitu:

(1) Pengendalian Internal Akuntansi

Meliputi struktur organisasi, metode, dan ukuran-ukuran yang dikordinasikan terutama untuk menjaga kekayaan organisasi serta mengecek ketelitian dan keandalan data akuntansi.
(2) Pengendalian Internal Administratif

Meliputi struktur organisasi, metode, dan ukuran-ukuran yang dikordinasikan terutama untuk menjamin efisiensi dan kepatuhan atas kebijakan pimpinan.

Menurut Bastian (2011), unsur-unsur pokok dalam sistem pengendalian internal adalah sebagai berikut:

(1) Struktur organisasi yang memisahkan tanggung jawab fungsional secara tegas. Struktur organisasi memisahkan tanggung jawab fungsional secara tegas. Pemisahan fungsi akuntansi antara fungsifungsi operasi dengan fungsi penyimpanan akan membantu catatan akuntansi yang diselenggarakan dapat mencerminkan transaksi yang sesungguhnya.

(2) Sistem wewenang dan prosedur pencatatan yang memberikan perlindungan yang memadai terhadap kekayaan, utang, pendpaatan, dan biaya. Dalam organisasi setiap transaksi hanya terjadi berdasarkan otorisasi dari pejabat yang memiliki wewenang untuk menyetujui. Penggunaan wewenang dalam memberikan otorisasi atas terlaksananya suatu transaksi terekam dalam dokumen yang akan dipakai sebagai dasar untuk mencatat transaksi. Prosedur pencatatan dengan sistem otorisasi yang baik akan menghasilkan informasi akuntansi yang teliti dan dapat dipercaya.

(3) Praktik yang sehat dalam melaksanakan tugas dan fungsi dari setiap unit organisasi. Praktik yang sehat meliputi penggunaan formulir yang pemakaiannya harus dipertanggungjawabkan oleh pihak yang berwenang, pemeriksaan mendadak, setiap transaksi tidak boleh dilakukan dari awal sampai akhir oleh satu orang atau satu unit organisasi, adanya perputaran jabatan) untuk menjaga independensi tugas, pencocokan fisik aset dengan catatannya secara periodik, terdapat unit pengawasan internal.

(4) Karyawan yang kompetensinya sesuai dengan tanggung jawabnya. Bagaimanapun baiknya struktur organisasi, sistem otorisasi, prosedur pencatatan dan cara yang diciptakan untuk mendorong praktik sehat, semuanya tergantung dari manusia yang melaksanakannya. Pengendalian internal yang diberikan dapat disesuaikan dengan kompetensi sumber daya manusia yang dimiliki.

\section{Hubungan Kualitas Sistem dan Kepuasan Pengguna}

Ukuran kepuasan pemakai pada sistem komputer dicerminkan oleh kualitas sistem yang diguna- 
kan (Istianingsih dan Utami, 2009). Sistem yang berkualitas akan membantu pengguna dalam menyelesaikan pekerjaan yang dibebankan. Semakin baik kualitas sistem maka pengguna akan semakin merasa terbantu (Arfinin dan Pratolo, 2012). Apabila kualitas sistem informasi adalah baik menurut persepsi penggunanya, maka pengguna cenderung akan merasa puas dalam menggunakan sistem tersebut. Semakin tinggi kualitas sistem informasi yang digunakan, diprediksi akan berpengaruh terhadap semakin tingginya tingkat kepuasan pengguna akhir sistem informasi tersebut. Berdasarkan uraian di atas penelitian ini menghipotesakan bahwa semakin tinggi kualitas paket program aplikasi (software) akuntansi yang digunakan, akan meningkatkan kepuasan pemakai menurut mereka.

Yusof et al. (2006) menyatakan bahwa (HOT) Fit Framework mengukur keberhasilan sistem informasi dengan melihat kesesuaian teknologi yang digunakan dengan pengguna teknologi, kualitas sistem diasosiasikan sebagai kinerja sistem. Kualitas sistem merupakan salah satu variabel yang digunakan untuk mengukur faktor teknologi dalam (HOT) Fit Framework. Teknologi yang dianggap sesuai (Fit) dengan faktor pengguna (human) ditunjukkan dengan pengaruh kualitas sistem terhadap kepuasan pengguna.

Penelitian Istianingsih dan Utami (2009) serta Santoso (2012) menemukan bahwa semakin baik kualitas sistem maka akan meningkatkan kepuasan pengguna. Penelitian Istianingsih dan Utami (2009), Sudarmadi (2010), serta Santoso (2012) menemukan bahwa kualitas informasi sistem akan mempengaruhi kepuasan pengguna. Pengguna sistem informasi pasti berharap bahwa dengan menggunakan sistem tersebut akan diperoleh informasi (output) yang dibutuhkan. Karakteristik informasi yang dihasilkan suatu sistem informasi dapat saja berbeda dengan output dari sistem informasi yang lain. Sistem informasi yang mampu menghasilkan informasi yang tepat waktu, akurat, sesuai kebutuhan, dan relevan serta memenuhi kriteria dan ukuran lain tentang kualitas informasi akan mempengaruhi kepuasan penggunanya. Semakin tinggi kualitas informasi yang dihasilkan statu sistem informasi, diprediksi akan berpengaruh terhadap semakin tingginya kepuasan pengguna akhir suatu sistem informasi. Berdasarkan argumentasi tersebut, maka dirumuskan hipotesis sebagai berikut:

$\mathrm{H}_{1}$ : Kualitas SIMDA BMD berpengaruh terhadap kepuasan pengguna.

\section{Hubungan Kualitas Sistem dan Pengendalian Organisasi}

Penelitian Poluan et al. (2014) menemukan bahwa faktor teknologi memiliki hubungan yang kuat, searah dan signifikan terhadap organisasi. Semakin tepat dan baik kualitas teknologi yang diterapkan dalam organisasi untuk mendukung tujuan, visi, dan misi organisasi, serta peningkatan fasilitas terhadap teknologi, maka akan meningkatkan kinerja organisasi. Mohamadali dan Garibaldi (2012) mengemukakan bahwa pentingnya konsep kesesuaian (fit) antara sistem (technology) yang digunakan dengan pengendalian organisasi sangat diperlukan, karena teknologi yang digunakan akan mempengaruhi organisasi dalam menyusun strategi dan merencanakan rangkaian pengendalian yang akan dilakukan dalam mencapai tujuan organisasi. Penelitian Yusof dan Yusuff (2013) pada sistem informasi pemerintahan di Malaysia menemukan bahwa dengan adanya kesesuaian (fit) antara sistem (technology) dengan pengendalian organisasi (organization) yang diberikan akan membantu melahirkan strategi dalam menyediakan pelayanan yang baik.

Penggunaan teknologi informasi dalam melakukan pengelolaan barang milik daerah diatur dalam pasal 98 Perda Kota Mataram No. 17 Tahun 2011 tentang Pengelolaan Barang Milik Daerah, yang berbunyi:

"Untuk memudahkan pendaftaran, pencatatan dan pelaporan barang milik daerah sebagaimana dimaksud dalam Pasal 93, Pasal 94, Pasal 95, dan Pasal 96 secara cepat dan akurat, pengelolaan barang milik daerah harus menggunakan Sistem Informasi Manajemen Barang Milik Daerah berbasis komputer”.

Keharusan penggunaan SIMDA BMD sebagai mandatory system dalam pengelolaan pencatatan dan pelaporan barang milik daerah mengakibatkan penyesuaian pengendalian internal yang akan diberikan organisasi. Adanya tuntutan dalam pelayanan yang cepat dan akurat, merupakan pencapaian yang harus diperhatikan oleh organisasi. Diharapkan dengan semakin baik kualitas sistem (technology) yang digunakan maka semakin baik pengendalian yang akan dilakukan organisasi dalam mencapai tujuan organisasi. Berdasarkan argumentasi tersebut, maka dirumuskan hipotesis sebagai berikut

$\mathrm{H}_{2}$ : Kualitas SIMDA BMD berpengaruh terhadap pengendalian organisasi.

\section{Hubungan Timbal Balik (Reciproca) antara Kepuasan Pengguna dan Kualitas Informasi Aset Tetap}

Penelitian Sudamadi (2010) mengemukakan bahwa kepuasan pengguna sistem informasi merupakan indikator keberhasilan penerapan sistem informasi. Istianingsih dan Utami (2009) dalam hasil penelitiannya menemukaan bahwa kepuasan peng- 
guna berpengaruh positif pada kinerja individual. Santoso (2012) dan laksono (2015) membuktikan bahwa kepuasan pengguna akan berpengaruh terhadap manfaat bersih yang diperoleh dari sistem informasi. Manfaat yang hendak diperoleh dari penggunaan SIMDA BMD adalah pengguna dapat menyajikan informasi aset tetap yang berkualitas untuk mensukseskan implementasi kebijakan Restatement aset tetap kedalam neraca berbasis akrual.

Penelitian Darwanis dan Mahyani (2009) menemukan bahwa pemanfaatan sistem informasi akan mempengaruhi kepuasan pengguna yang pada akhirnya akan meningkatkan keterandalan pelaporan keuangan. Hasil yang berbeda diperoleh dalam Penelitian Indriasari dan Nahartyo (2008) yang menemukan bahwa kapasitas sumber daya manusia hanya mempengaruhi ketepatwaktuan informasi, namun tidak mempengaruhi keandalan informasi. Karmila et al. (2014) juga menemukan kapasitas SDM (pengguna) tidak berpengaruh dalam meningkatkan keterandalan informasi pelaporan keuangan.

(HOT) Fit Framework yang dikemukakan oleh Yusof et al. (2006) menyatakan bahwa faktor manusia sangat berpengaruh terhadap manfaat bersih yang dihasilkan sistem, semakin meningkatnya kepuasan pengguna maka semakin besar menfaat bersih yang didapat dari sistem. Yusof et al. (2008) dalam penelitiannya juga menegaskan hubungan dua arah (reciprocal) antara organisasi (organization) dan manfaat bersih (net benefits) yang diperoleh dari sistem. Yusof et al. (2008) mengemukakan bahwa: "Two-way relationships between these dimensions: ... System Use and User Satisfaction are direct antecedents of Net Benefits. Net Benefits subsequently affect System Use and User Satisfaction. Dalam Model (HOT) Fit Framework kepuasan pengguna yang merupakan bagian dari faktor manusia, mempunyai hubungan dua arah (reciprocal) dengan $\mathrm{Net}$ Benefit (dalam penelitian ini diukur dengan kualitas informasi aset yang dihasilkan). Faktor pengguna (human) merupakan faktor yang dominan dalam menggali potensi sistem informasi agar dapat memberikan manfaat yang diharapkan oleh pengguna maupun organisasi (Nasir dan Syaputra, 2014). Kepuasan pengguna akan meningkatkan kinerja individual (Istianingsih dan Utami, 2009). Lebih lanjut kinerja individu yang bagus akan membantu individu dalam menyelesaikan tugas yang diberikan.

Tujuan penggunaan SIMDA BMD adalah membantu pengelolaan data aset tetap menjadi informasi aset tetap yang dapat disajikan pada laporan keuangan. Semakin tinggi kepuasan pengguna terhadap bantuan SIMDA BMD dalam mengolah data aset tetap menjadi informasi aset tetap, maka semakin meningkatkan kualitas informasi aset tetap yang akan dapat diperoleh. Kebijakan restatement aset tetap membutuhkan peran besar juga dari sumber daya manusia, dalam hal ini pengguna SIMDA BMD agar dapat menyajikan informasi aset yang berkualitas, sehingga penyajian kembali akun aset tetap pada neraca berbasis akrual dapat dilaksanakan dengan baik. Berdasarkan argumentasi tersebut, maka dirumuskan hipotesis sebagai berikut:

$\mathrm{H}_{3 a}$ : Kepuasan pengguna berpengaruh terhadap kualitas informasi aset tetap.

$\mathrm{H}_{3 \mathrm{~b}}$ : Kualitas informasi aset tetap berpengaruh terhadap kepuasan pengguna.

\section{Hubungan Timbal Balik (Reciproca) Antara Pengendalian Organisasi dan Kualitas Informasi Aset Tetap}

Komara (2006) dan Poluan et al. (2014) menemukan bahwa dukungan manajemen yang baik dapat meningkatkan penggunaan sistem informasi. Diana (2014) juga menemukan bahwa faktor organisasi berpengaruh pada penggunaan sistem informasi. Apabila penggunaan sistem informasi sudah diterima maka pengguna terbantu mengerjakan tugas yang dibebankan. Pengendalian organisasi berpengaruh terhadap tingkat kesuksesan pemanfaatan sistem informasi dalam organisasi tersebut. Pengendalian organisasi dalam penelitian ini terdiri dari pengendalian layanan pengoperasian SIMDA BMD, pengendalian internal akuntansi dan pengendalian internal administratif. Penelitian Indriasari dan Nahartyo (2008) menemukan bahwa pengendalian intern akuntansi dari organisasi akan meningkatkan nilai informasi dari laporan keuangan yang dibuat organisasi. Temuan serupa juga dikuatkan oleh Darwanis dan Mahyani (2009) yang menemukan bahwa pengendalian internal akuntansi dari organisasi akan meningkatkan keterandalan dari laporan keuangan yang dihasilkan.

Poluan et al. (2014) dalam penelitiannya menemukan bahwa net benefit yang diperoleh dari sistem yang digunakan akan rendah jika pengaruh organisasi yang diberikan rendah. Diperlukan pembenahan dari layanan yang diberikan organisasi untuk lebih meningkatkan net benefit dari sistem. Nasyir dan Syaputra (2014) dalam penelitiannya membuktikan bahwa variabel organisasi mempengaruhi manfaat bersih yang akan diperoleh dari penerapan sistem. Indikator yang terbukti paling dominan dari variabel organisasi adalah spesifikasi tugas dan tanggung jawab untuk menggunakan sistem, evaluasi terhadap sistem dan pelayanan, pernyataan, kemampuan lingkungan kerja organisasi dalam mendukung penggunaan sistem, serta apresiasi (reward) bagi prestasi yang diperoleh dalam penggunaan sistem. Indikator-indikator tersebut menegaskan pentingnya pengendalian organisasi 
dalam memperoleh manfaat dari penerapan sistem. Berdasarkan argumentasi tersebut, maka dapat dinyatakan bahwa:

$\mathrm{H}_{\text {a: }}$ : Pengendalian organisasi berpengaruh terhadap kualitas informasi aset tetap.

Penelitian ini juga akan melihat pengaruh tuntutan kebutuhan informasi aset tetap yang berkualitas terhadap pengendalian organisasi yang diberikan. Kualitas informasi aset tetap bukan hanya dipengaruhi oleh pengendalian organisasi, tetapi dapat terjadi sebaliknya, dengan semakin meningkatnya tuntutan akan informasi aset tetap yang berkualitas justru akan mempengaruhi organisasi untuk harus tanggap dalam menyesuaikan strategi pengendaliannya. Hal ini didukung dengan temuan dalam penelitian Nasyir dan Syaputra (2014) yang membuktikan bahwa indikator kesempatan untuk memperbaiki kesalahan dalam lingkungan kerja sehingga dapat bersinergi dengan keberadaan sistem dalam memberikan manfaat merupakan indikator yang dominan. Pengendalian organisasi harus dapat menyesuaikan dengan tuntutan tugas yang dibebankan.

Yusof et al. (2008) dalam penelitiannya juga menegaskan hubungan dua arah (reciproca) antara organisasi (organization) dan manfaat bersih (net benefits) yang diperoleh dari sistem. Yusof et al. (2008) mengemukakan bahwa: "Two-way relationships between these dimensions:... Organizational Structure and Net Benefits, Organizational Environment and Net Benefits". Pada ranah sektor publik, meningkatnya tuntutan terhadap kualitas informasi keuangan dalam pelaporan akan mempengaruhi kebijakan yang dibuat dalam rangka penyesuaian pengendalian untuk mencapai tujuan organisasi.
Pada Pemerintah Kota Mataram tuntutan akan kualitas informasi aset tetap yang sesuai dengan penerapan SAP berbasis akrual (Permendagri Nomor 64 Tahun 2013 tentang Penerapan Standar Akuntansi Pemerintah Berbasis Akrual pada Pemerintah Daerah) mendorong lahirnya Peraturan Walikota No. 13 Tahun 2014 tentang Kebijakan Akuntansi Pemerintah Kota Mataram. Kebijakan akuntansi tersebut dibuat untuk mengakomodasi kebutuhan perubahan perlakuan akuntansi dengan diwajibkannya SAP berbasis akrual pada pemerintah daerah di Indonesia. Perubahan kebijakan akuntansi akan berimplikasi pada perubahan kualifikasi informasi keuangan yang dibutuhkan, sehingga organisasi harus dapat menyesuaikan penyusunan strategi dalam melakukan pengendalian. Berdasarkan argumentasi yang dipaparkan di atas, maka dirumuskan hipotesis sebagai berikut:

$\mathrm{H}_{4 \mathrm{~b}}$ : Semakin meningkat kebutuhan kualitas informasi aset tetap maka pengendalian organisasi yang diberikan akan semakin ditingkatkan.

\section{METODE PENELITIAN}

\section{Populasi dan Sampel}

Populasi penelitian ini adalah 90 responden yang mewakili seluruh Satuan Kerja Perangkat Daerah (SKPD) pada Pemerintah Kota (Pemkot) Mataram dengan menggunakan kuesioner. Kelompok responden adalah pengurus barang (operator SIMDA BMD), admin SIMDA BMD, serta pejabat penatausahaan aset yang berwenang pada Pemkot Mataram.Pengambilan sampel menggunakan purposive sampling dengan kriteria sebagai berikut:

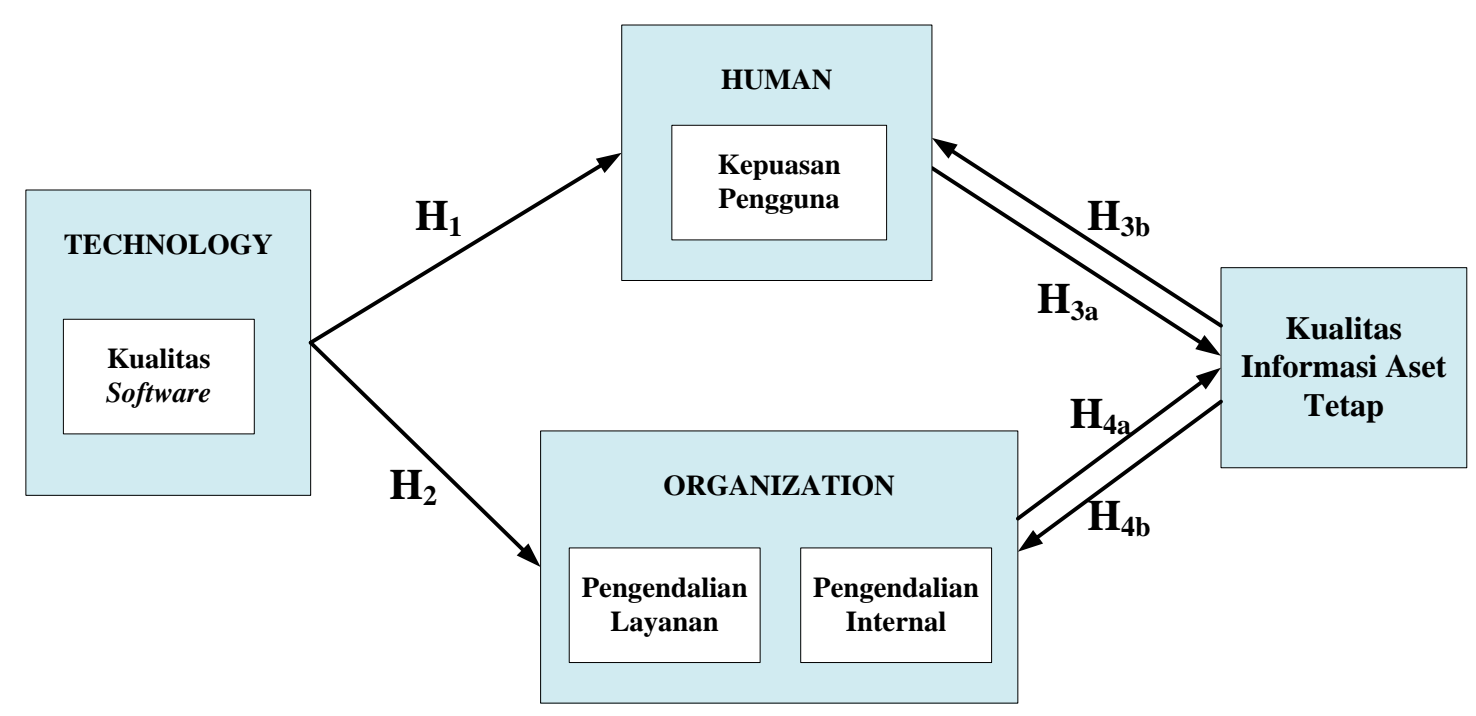

Gambar 2. Rerangka Konseptual Penelitian 
(1) Pejabat eselon IV yang mengatur masalah penatausahaan aset tetap dan pengendalian internal masing-masing SKPD yaitu Kasubag Umum \& Kepegawaian.

(2) Pejabat pengelola barang milik daerah yang berhubungan langsung dengan kegiatan penatausahaan aset tetap yang menggunakan SIMDA BMD, yang terdiri atas:

a) Kepala Bidang Aset, Kepala Sub Bidang Penatausahaan Aset, serta staf yang menjadi satuan petugas (Satgas) SIMDA BMD yang ada di sub bidang penatausahaan aset daerah BPKAD selaku kordinator pengendalian layanan SIMDA BMD dan kordinator pengendalian penatausahaan aset daerah lingkup Pemerintah Kota Mataram.

b) Pengurus barang yang ada di masing-masing SKPD selaku operator pengolah data aset tetap dengan menggunakan SIMDA BMD (pengguna sistem).

Adapun alasan pemilihan dengan beberapa kriteria tersebut adalah karena untuk mengukur pengendalian internal organisasi maka responden harus merupakan pejabat yang berperan mengatur sistem pengendalian internal organisasi dalam kegiatan pengelolaan aset tetap daerah. Pemilihan pengguna SIMDA BMD sebagai responden disesuaikan sebagai elemen populasi yang spesifik dan relevan dengan tujuan dan masalah penelitian. Lebih lanjut seluruh pejabat dan staf pada bidang penatausahaan aset daerah BPKAD adalah kordinator pengendali layanan yang bertanggungjawab dalam pelaksanaan penatausahaan aset daerah dan pengelolaan data aset daerah menggunakan SIMDA BMD di lingkup Pemerintah Kota Mataram.

\section{Variabel dan Pengukurannya}

\section{Kualitas SIMDA BMD}

SIMDA BMD merupakan sistem informasi yang digunakan untuk pengolahan data aset tetap. Sebuah sistem informasi akan menerima input berupa data mentah kemudian diproses menjadi informasi dalam bentuk keluaran (output). Menurut Yusof et al. (2006), kualitas sistem diasosiasikan sama dengan kinerja sistem. Kualitas sistem dalam sistem informasi menyangkutketerkaitan fitur dalam sistem termasuk performa sistem dan user interface (Krisbiantoro et al., 2015). Kualitas sistem yang baik akan memenuhi kebutuhan pengguna dan mudah digunakan, sehingga dapat membantu tugas yang dikerjakan pengguna (Yusof et al., 2008). Dalam penelitian ini kualitas SIMDA BMD diukur dengan kualitas software SIMDA BMD. Kualitas software adalah kualitas SIMDA BMD sebagai sebuah perangkat lunak yang dikukur berdasarkan kemudahan penggunaannya, efisiensi sistem, keandalan dan kegunaan fitur dan fungsi yang dimiliki sistem.

\section{Kepuasan Pengguna}

Kepuasan pengguna adalah keseluruhan evaluasi dari pengalaman pengguna dalam menggunakan sistem informasi dan dampak potensial dari sistem informasi (Yusof et al., 2006). Kepuasan pengguna dapat dihubungkandengan persepsi manfaat (usefulness) dan sikap pengguna terhadap sistem informasi yang dipengaruhioleh karakteristik personal (Yusof et al., 2008). Kepuasan pengguna sistem merupakan respon dan umpan balik yang dimunculkan pengguna setelah memakai sistem informasi. Sikap pengguna terhadap sistem informasi merupakan kriteria subjektif mengenai seberapa puas pengguna terhadap sistem yang digunakan. Dalam penelitian ini kepuasan pengguna diukur dengan:

(1) Perceived usefulness

merupakan persepsi pengguna tentang kebermanfaatan penggunaan sebuah sistem informasi. Persepsi ini diindikasikan dengan persepsi pengguna atas peningkatan produktifitas kerja, tingkat penggunaan dan tingkat kenyamanan yang dirasakan.

(2) Overall satisfaction

merupakan kepuasan yang dirasakan pengguna setelah menggunakan SIMDA BMD. Dimensi kepuasan ini diindiksikan dengan kepuasan terhadap antar muka (interface) maupun terhadap fitur-fitur SIMDA BMD secara spesifik (software satisfaction), tidak adanya kesenjangan informasi antara informasi yang diharapkan pengguna dengan informasi yang didapatkan dari sistem (information gap), dan kepuasan dalam proses pengambilan keputusan (decision making satisfaction) yang melibatkan penggunaan sistem maupun dibantu dengan hasil informasi dari SIMDA BMDA.

(3) Pengendalian Organisasi adalah serangkaian kegiatan pengendalian internal yang meliputi struktur organisasi, metode, dan ukuran-ukuran yang dikoordinasikan untuk menjaga kekayaan organisasi, mengecek ketelitian dan keandalan data akuntansi, mendorong efisiensi, dan dipatuhinya kebijakan pimpinan (Bastian, 2011). Pengendalian organisasi dalam penelitian ini diukur dengan:

a) Pengendalian Layanan

Menurut Yusof et al. (2006), kualitas pelayanan berhubungan dan berfokus pada keseluruhan dukungan yang diterima dari penyedia 
layanan (service provider) sistem, tanpa membedakan pelayanan diberikan bagian internal organisasi atau vendor eksternal. Penggunaan SIMDA BMD di lingkup Pemerintah Kota Mataram dikordinasikan oleh Bidang Aset di BPKAD Kota Mataram, sedangkan vendor yang membuat dan mengembangkan aplikasi SIMDA BMD adalah BPKP. Berdasarkan penyedia layanan, maka pengukuran kualitas pelayanan bisa diukur dari kualitas pelayanan yang diperoleh pengguna dari Bidang aset BPKAD maupun dari BPKP. Dalam penelitian ini kualitas pelayanan diukur dengan: jaminan kelancaran pengoperasian sistem dari Bidang Penatausahaan Aset BPKAD sebagai kordinator penatausahaan aset tetap di lingkup Pemerintah Kota Mataram dan admin SIMDA BMD, empati, serta dukungan teknis yang diberikan terhadap permasalahan penatausahaan aset yang melibatkan SIMDA BMD.

b) Pengendalian Internal

Pengendalian Internal; berfokus pada kegiatan pengendalian dalam rangka menjamin efisiensi dan kepatuhan atas kebijakan akuntansi yang diberlakukan. Pengendalian ini diindikasikan dengan adanya pelatihan SIMDA BMD, sosialisasi, kepatuhan atas regulasi, komitmen pimpinan, adanya program khusus, reward, punishment, dan evaluasi penerapan kebijakan.

\section{Kualitas Informasi Aset Tetap}

Kualitas informasi merupakan informasi akuntansi yang terdapat di dalam laporan keuangan pemerintah daerah yang memenuhi karakteristik kualitatif sebagaimana disyaratkan dalam Peraturan Pemerintah No. 71 Tahun 2010 tentang Standar Akuntansi Pemerintahan. Pada SAP berbasis akrual, neraca merupakan salah satu komponen laporan keuangan yang harus ada. Salah satu informasi yang disajikan dalam neraca adalah informasi mengenai aset tetap. Agar neraca berbasis akrual dapat memenuhi kualitas dapat dibandingkan, maka harus dilakukan penyajian kembali (restatement) informasi aset tetap. Agar neraca yang dibuat memenuhi kualitas yang disyaratkan maka informasi aset tetap juga harus memenuhi karakteristik kualitatif pada PP No. 71 Tahun 2010. Jadi kualitas informasi aset tetap diukur dengan sejauh mana informasi secara konsisten dapat memenuhi persyaratan kualitatif pada PP No. 71 Tahun 2010 dan harapan semua pengguna informasi (Surastiani dan Handayani, 2015), terutama dalam rangka pelaksanaan penyajian kembali (restatement) informasi aset tetap pada neraca akrual. Dalam penelitian ini kualitas informasi aset tetap diukur dengan:
(1) Dimensi relevan, dengan indikator yang meliputi: manfaat umpan balik, manfaat prediktif, tepat waktu dan lengkap.

(2) Dimensi andal, dengan indikator yang meliputi informasi yang disajikan jujur, dapat diverifikasi, tidak memihak atau sesuai prinsip netralitas.

(3) Dimensi Dapat dibandingkan, dengan indikator yang meliputi informai aset tetap dapat dibandingkan antar periode dan dapat dilihat perbaikan informasi dengan penerapan kebijakan baru.

(4) Dimensi Dapat dipahami, dengan indikator yang meliputi informai aset tetap dilengkapi pengungkapan yang memadai serta bentuk penyajian sesuai dengan prinsip akuntansi berlaku umum sehingga mudah dipahami pengguna laporan.

\section{Analisis Data}

Penelitian ini melibatkan satu variabel eksogen (kualitas SIMDA BMD) dan tiga variabel endogen (kepuasan pengguna, pengendalian organisasi dan kualitas informasi aset tetap). Teknik analisis statistik yang digunakan dalam penelitian ini adalah structural equation model (SEM) dengan alat analisis Generalized Structured Component Analysis (GeSCA). Alasan penggunaan GeSCA adalah, pertama karena dalam penelitian ini terdapat variabel-variabel laten yang memiliki pengaruh bolak-balik (reciprocal) yaitu hubungan reciprocal antara variabel kepuasan penggunadan variabelpengendalian organisasi dan hubungan reciprocalantara pengendalian organisasi dan kualitas informasi.

Model struktural dan pengukuran diuji dengan persamaan struktural sebagai berikut :

$\begin{array}{lll}\mathrm{KP} & =\gamma_{1} \mathrm{KS}+\beta_{1} \mathrm{KIAT}+\zeta_{1} \ldots \ldots \ldots \ldots . .(1) \\ \mathrm{PO} & =\gamma_{2} \mathrm{KS}+\beta_{2} \mathrm{KIAT}+\zeta_{2} \ldots \ldots \ldots \ldots .(2) \\ \text { KIAT } & =\beta_{3} \mathrm{KP}+\beta_{4} \mathrm{PO}+\zeta_{3} \ldots \ldots \ldots \ldots \ldots . .(3)\end{array}$

Persamaan model pengukuran adalah:

$\mathrm{KS}=\lambda_{11} \mathrm{X}_{1.1}+\lambda_{12} \mathrm{X}_{1.2}+\lambda_{13} \mathrm{X}_{1.3}+\lambda_{14} \mathrm{X}_{1.4}+\lambda_{15} \mathrm{X}_{1.5}+$

$\lambda_{16} \mathrm{X}_{1.6}+\lambda_{17} \mathrm{X}_{1.7}+\lambda_{18} \mathrm{X}_{1.8}+\lambda_{19} \mathrm{X}_{1.9}+\lambda_{10} \mathrm{X}_{1.10}+$ $\varepsilon_{1}$

$\mathrm{KP}=\lambda_{211} \mathrm{Y}_{1.1}+\lambda_{212} \mathrm{Y}_{1.2}+\lambda_{213} \mathrm{Y}_{1.3}+\lambda_{214} \mathrm{Y}_{1.4}+$ $\lambda_{215} \mathrm{Y}_{1.5}+\lambda_{216} \mathrm{Y}_{1.6}+\lambda_{221} \mathrm{Y}_{2.1}+\lambda_{222} \mathrm{Y}_{2.2}+$ $\lambda_{223} \mathrm{Y}_{2.3}+\lambda_{224} \mathrm{Y}_{2.4}+\lambda_{225} \mathrm{Y}_{2.5}+\lambda_{226}+\mathrm{Y}_{2.6}+$ $\lambda_{227} \mathrm{Y}_{2.7}+\lambda_{228} \mathrm{Y}_{2.8}+\varepsilon_{2}$

$\mathrm{PO}=\lambda_{31} \lambda_{311} \mathrm{Y}_{3.1}+\lambda_{312} \mathrm{Y}_{3.2}+\lambda_{313} \mathrm{Y}_{3.3}+\lambda_{314} \mathrm{Y}_{3.4}+$ $\lambda_{315} \mathrm{Y}_{3.5}+\lambda_{316} \mathrm{Y}_{3.6}+\lambda_{317} \mathrm{Y}_{3.7}+\lambda_{318} \mathrm{Y}_{3.8}+\lambda_{319} \mathrm{Y}_{3.9}+$ $\lambda_{3110} \mathrm{Y}_{3.10}+\lambda_{321} \mathrm{Y}_{4.1}+\lambda_{322} \mathrm{Y}_{4.2}+\lambda_{323} \mathrm{Y}_{4.3}+$ $\lambda_{324} \mathrm{Y}_{4.4}+\lambda_{325} \mathrm{Y}_{4.5}+\lambda_{326} \mathrm{Y}_{4.6}+\lambda_{327} \mathrm{Y}_{4.7}+$ $\lambda_{328} \mathrm{Y}_{4.8}+\lambda_{329} \mathrm{Y}_{4.9}+\lambda_{3210} \mathrm{Y}_{4.210}+\lambda_{3211} \mathrm{Y}_{4.211}+$ $\lambda_{3212} \mathrm{Y}_{4.12}+\lambda_{3213} \mathrm{Y}_{4.213}+\lambda_{3214} \mathrm{Y}_{4.14}+\varepsilon_{3}$ 
$\mathrm{KIAT}=\lambda_{411} \mathrm{Y}_{6.1}+\lambda_{412} \mathrm{Y}_{6.2}+\lambda_{413} \mathrm{Y}_{6.3}+\lambda_{414} \mathrm{Y}_{6.4}+$ $\lambda_{421} \mathrm{Y}_{7.1}+\lambda_{422} \mathrm{Y}_{7.2}+\lambda_{423} \mathrm{Y}_{7.3}+\lambda_{424} \mathrm{Y}_{7.4}+\lambda_{431}$ $\mathrm{Y}_{8.1}+\lambda_{432} \mathrm{Y}_{8.2}+\lambda_{441} \mathrm{Y}_{9.1}+\lambda_{442} \mathrm{Y}_{9.2}+\varepsilon_{4}$

Keterangan:

- $\quad \gamma($ Gama $)=$ koefisien pengaruh variabel eksogen terhadap variabel endogen
- $\quad \beta($ Beta $)=$ koefisien pengaruh variabel endogen terhadap variabel endogen

- $\quad \zeta($ Zeta $)=$ galat model struktural

- $\lambda($ Lambda $)=$ koefisien model pengukuran (loading weight);

- $\quad \varepsilon($ epsilon $)=$ galat model pengukuran

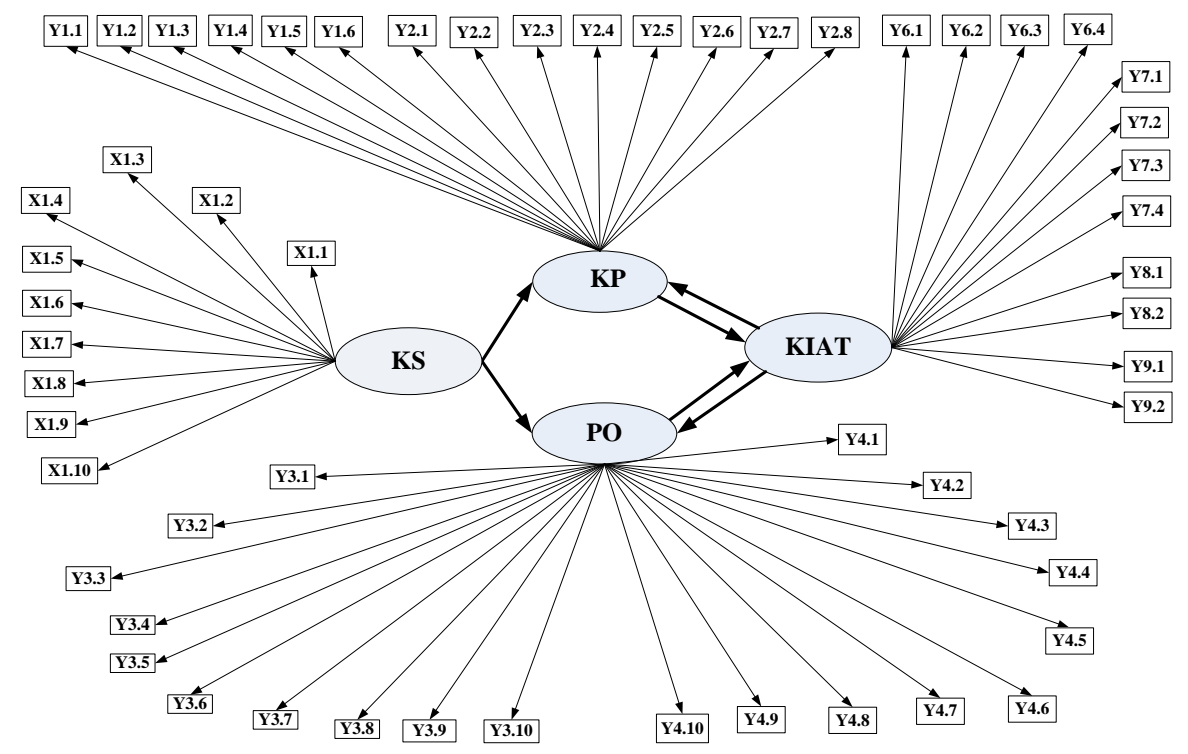

Gambar 3. Model Struktural dan Pengukuran

\section{HASIL DAN PEMBAHASAN}

\section{Hasil Pengujian Model Pengukuran, Model Struktural dan Goodness of Fit}

Hasil pengujian model pengukuran menunjukkan nilai loading factor $>0.5$, sehingga dapat disimpulkan bahwa seluruh indikator dalam model telah memenuhi syarat convergent validity (Ghozali dan Kusumadewi, 2013). Perbandingan hasil square root AVE masing-masing variabel dan korelasinya dengan variabel lain dalam model disajikan pada Tabel 1. Berdasarkan Tabel 1 diketahui bahwa semua variabel telah memenuhi discriminant validity yang baik. Untuk mengukur reliabilitas konstruk atau Composite Reliability dalam penelitian ini dilakukan dengan ukuran Cronbach Alpha, dengan ketentuan konstruk atau variabel laten dapat dikatakan reliabel jika memiliki nilai Cronbach Alpha > 0.7 (Sofyani dan Akbar, 2013; 2015). Hasil analisis Composite Reliability dapat dilihat pada Tabel 2.

\section{Hasil Pengujian Hipotesis}

Ringkasan hasil pengujian model struktural untuk masing-masing hipotesis disajikan pada Tabel 3, serta hasil evaluasi model fit disajikan pada Tabel 4 . Hasil pengujian hipotesis 1 menunjukkan bahwa kualitas software berpengaruh signifikan dan positif terhadap kepuasan pengguna, sehingga semakin meningkat kualitas software SIMDA BMD maka kepuasan pengguna juga akan meningkat. Hasil penelitian ini mendukung temuan pada penelitian Yusof et al. (2006), Istianingsih dan Utami (2009), Santoso (2012), Yusof dan Yusuff (2013), serta Krisbiantoro et al. (2015), yang menyatakan bahwa semakin meningkat kualitas sistem maka kepuasan pengguna juga semakin meningkat. Hal ini dikarenakan sistem yang berkualitas akan membantu pengguna dalam menyelesaikan pekerjaan yang dibebankan, sehingga semakin baik kualitas sistem maka pengguna akan semakin merasa terbantu.

Apabila kualitas sistem informasi adalah baik menurut persepsi penggunanya, maka pengguna cenderung akan merasa puas dalam menggunakan sistem tersebut. Semakin tinggi kualitas sistem informasi yang digunakan, diprediksi akan berpengaruh terhadap semakin tingginya tingkat kepuasan pengguna akhir sisteminformasi tersebut. Temuan pada penelitian ini mendukung teori yang pada model HOT-Fit Framework yang dikemukakan Yusof et al. (2006) dimana faktor technology yang 
Tabel 1. PerbandinganSquare Root AVE dengan Korelasi Antar Variabel Laten

\begin{tabular}{|c|c|c|c|c|c|}
\hline No & Variabel & $\begin{array}{l}\text { Nilai } \\
\text { AVE }\end{array}$ & $\sqrt{A V E}$ & $\begin{array}{c}\text { Korelasi dengan } \\
\text { Variabel Lain }\end{array}$ & Keterangan \\
\hline \multirow{3}{*}{1} & \multirow{3}{*}{$\begin{array}{c}\text { Kualitas SIMDA } \\
\text { BMD (KS) }\end{array}$} & \multirow{3}{*}{0,517} & \multirow{3}{*}{0,720} & $\mathrm{KS}$ dengan $\mathrm{KP}=0.687$ & Memenuhi discriminant validity \\
\hline & & & & $\mathrm{KS}$ dengan $\mathrm{PO}=0.454$ & Memenuhi discriminant validity \\
\hline & & & & KS dengan KI_AT $=0.151$ & Memenuhi discriminant validity \\
\hline \multirow{3}{*}{2} & \multirow{4}{*}{$\begin{array}{c}\text { Kepuasan } \\
\text { Pengguna (KP) }\end{array}$} & \multirow{4}{*}{0,55} & \multirow{4}{*}{0,742} & $\mathrm{KP}$ dengan $\mathrm{KS}=0.687$ & Memenuhi discriminant validity \\
\hline & & & & $\mathrm{KP}$ dengan $\mathrm{PO}=0.545$ & Memenuhi discriminant validity \\
\hline & & & & KP dengan KI_AT = 0.384 & Memenuhi discriminant validity \\
\hline \multirow{3}{*}{3} & & & & PO dengan $\mathrm{KS}=0.454$ & Memenuhi discriminant validity \\
\hline & \multirow{2}{*}{$\begin{array}{c}\text { Pengendalian } \\
\text { Organisasi (PO) }\end{array}$} & \multirow{2}{*}{0,481} & \multirow{2}{*}{0,693} & $\mathrm{PO}$ dengan $\mathrm{KP}=0.545$ & Memenuhi discriminant validity \\
\hline & & & & PO dengan KI_AT $=0.562$ & Memenuhi discriminant validity \\
\hline \multirow{3}{*}{4} & \multirow{3}{*}{$\begin{array}{c}\text { Kualitas Informasi } \\
\text { Aset Tetap } \\
\text { (KI_AT) }\end{array}$} & \multirow{3}{*}{0,417} & \multirow{3}{*}{0,646} & KI_AT dengan $\mathrm{KS}=0.151$ & Memenuhi discriminant validity \\
\hline & & & & KI_AT dengan $\mathrm{KP}=0.384$ & Memenuhi discriminant validity \\
\hline & & & & KI_AT dengan $\mathrm{PO}=0.562$ & Memenuhi discriminant validity \\
\hline
\end{tabular}

\section{Tabel 2. Hasil Composite Reliability}

\begin{tabular}{llcc}
\hline No & Variabel & Cronbach Alpha & Keterangan \\
\hline 1 & Kualitas Software & 0.877 & Memenuhi Composite Reliability \\
2 & Kepuasan Pengguna & 0.908 & Memenuhi Composite Reliability \\
3 & Pengendalian Organisasi & 0.895 & Memenuhi Composite Reliability \\
4 & Kualitas Informasi Aset Tetap & 0.845 & Memenuhi Composite Reliability \\
\hline
\end{tabular}

Tabel 3. Hasil Uji Model Struktural (Inner Model)

\begin{tabular}{lcccccc}
\hline $\begin{array}{l}\text { Hubungan } \\
\text { Variabel Laten }\end{array}$ & \multicolumn{3}{c}{ Path Coefficients } & Signifikansi & Tanda & Kesimpulan \\
Estimate & SE & CR & CR 1.96 & - $)$ & Hipotesis diterima \\
\hline KS->KP & 0.643 & 0.132 & 4.88 & signifikan & + & Hipotesis diterima \\
KS->PO & 0.378 & 0.162 & 2.34 & signifikan & + & Hipotesis ditolak \\
KP->KIAT & 0.111 & 0.222 & 0.5 & tidak signifikan & + & Hipotesis diterima \\
KIAT->KP & 0.287 & 0.143 & 2.01 & signifikan & + & Hipotesis diterima \\
KIAT->PO & 0.505 & 0.136 & 3.71 & signifikan & + & Hipotesis diterima \\
PO->KIAT & 0.501 & 0.166 & 3.02 & signifikan & + & \\
\hline
\end{tabular}

$\mathrm{CR}^{*}=$ signifikant pada level alpha 0,05

Tabel. 4 Evaluasi Model Fit

\begin{tabular}{cccc}
\hline Kriteria & Koefisien & Rule of Thumb & Hasil \\
\hline FIT & 0.478 & $\begin{array}{c}\text { Variance dari data (nilai } \\
\text { berkisar antara 0-1) }\end{array}$ & $\begin{array}{c}\text { Sebesar 47,8\% ragam dari semua variabel dapat } \\
\text { dijelaskan oleh model } \\
\text { GFI }\end{array}$ \\
SRMR & 0.956 & 0.90 & $\begin{array}{c}\text { Model memenuhi kriteria fit yang baik } \\
\text { Model mempunyai nilai SRMR yang mendukung } \\
\text { model fit }\end{array}$ \\
NPAR & 90 & $\begin{array}{c}\text { Menunjukkan besarnya } \\
\text { parameter bebas yang } \\
\text { diestimasi }\end{array}$ & $\begin{array}{c}\text { 90free parameter yang diestimasi termasuk } \\
\text { bobot, loading, dan koefisien jalur }\end{array}$ \\
\hline
\end{tabular}


diwakili oleh variabel kualitas sistem mempengaruhi faktor human yang diwakili oleh kepuasan pengguna. Yusof et al. (2006) menegaskan bahwa pengaruh kualitas sistem terhadap kepuasan pengguna meng indikasikan bahwa sistem telah dapat memenuhi kebutuhan pengguna dan membantu pengguna dalam menyelesaikan pekerjaan. Dengan demikian, hasil studi ini dapat menjadi tambahan bukti empiris mengenai pengaruh positif signifikan kualitas sistem terhadap kepuasan pengguna, serta menunjukkan bahwa SIMDA BMD telah cukup memenuhi kebutuhan pengguna dan cukup efisien dalam membantu proses penatausahaan aset tetap di lingkup Pemerintah Kota Mataram.

Hasil pengujian hipotesis 2 menunjukkan bahwa kualitas software berpengaruh positif dan signifikan terhadap pengendalian organisasi, dengan kata lain semakin meningkat kualitas software SIMDA BMD maka pengendalian organisasi yang diberikan juga semakin meningkat. Hasil penelitian ini sesuai dengan hasil penelitian Poluan et al. (2014) yang menemukan bahwa faktor teknologi memiliki hubungan yang kuat, searah dan signifikan terhadap organisasi. Semakin tepat dan baik kualitas teknologi yang diterapkan dalam organisasi untuk mendukung tujuan, visi, dan misi organisasi, serta peningkatan fasilitas terhadap teknologi, maka akan meningkatkan kinerja organisasi. Hasil penelitian ini mengindikasikan bahwa dengan kualitas software yang bagus, maka SIMDA BMD akan meningkatkan kinerja organisasi dalam melakukan pengendalian penatausahaan aset tetap daerah, baik itu dalam hal pengendalian internal akuntansi aset tetap maupun pengendalian administratif yang diberikan untuk mendukung penatausahaan aset tetap yang sesuai dengan peraturan yang berlaku (berdasarkan SAP berbasis akrual).

Hasil penelitian ini juga mendukung implikasi penelitian Mohamadali dan Garibaldi (2012) yang mengemukakan tentang pentingnya konsep kesesuaian (fit) antara sistem (technology) yang digunakan dengan pengendalian organisasi, karena teknologi yang digunakan akan mempengaruhi organisasi dalam menyusun strategi dan merencanakan rangkaian pengendalian yang akan dilakukan dalam mencapai tujuan organisasi. Begitu juga pada Pemerintah Kota Mataram, dengan menggunakan SIMDA BMD, maka proses penatausahaan aset tetap bisa dilakukan dengan lebih mudah dan terkomputerisasi. Temuan pada penelitian ini mendukung teori yang ditunjukkan pada model HOT-Fit Framework dimana faktor technology (dalam hal ini variabel kualitas software) berpengaruh terhadap faktor organisasi (dalam hal ini variabel pengendalian internal). Hasil penelitian ini juga mendukung temuan dalam penelitian Yusof dan Yusuff (2013) pada sistem infor- masi pemerintahan di Malaysia, yang menemukan bahwa dengan adanya kesesuaian (fit) antara sistem (technology) dengan pengendalian organisasi (organization) yang diberikanakan membantu melahirkan strategi dalam menyediakan pelayanan yang baik.

Penggunaan SIMDA BMD sebagai mandatory system (pasal 98 Perda Kota Mataram No. 17 Tahun 2011 tentang Pengelolaan Barang Milik Daerah) dalam pengelolaan pencatatan dan pelaporan barang milik daerah Pemerintah Kota Mataram mengakibatkan penyesuaian pengendalian internal yang akan diberikan organisasi. Adanya tuntutan dalam pelayanan yang cepat dan akurat, merupakan pencapaian yang harus diperhatikan oleh organisasi. Hasil penelitian ini memberikan implikasi bahwa dengan semakin baik kualitas SIMDA BMDyang digunakan maka semakin baik pengendalian yang akan dilakukan organisasi dalam mencapai tujuan organisasi.

Hasil pengujian hipotesis 3a menunjukkan bahwa tidak terdapat pengaruh kepuasan pengguna terhadap kualitas informasi aset tetap. Dari tabel 3 diketahui bahwa kepuasan pengguna berpengaruh positif terhadap kualitas informasi aset tetap tetapi tidak signifikan, dengan kata lain kepuasan pengguna tidak berpengaruh terhadap kualitas informasi aset tetap. Berdasarkan hasil pengujian diketahui bahwa hipotesis $3 \mathrm{~b}$ yang menyatakan bahwa terdapat pengaruh kualitas informasi aset tetap terhadap kepuasan pengguna diterima. Dari tabel 3 diketahui bahwa kualitas informasi aset tetap berpengaruh positif terhadap kepuasan pengguna dan signifikan, dengan kata lain kualitas informasi aset tetap berpengaruh terhadap kepuasan pengguna.

Disimpulkan bahwa tidak terdapat hubungan timbal balik (reciprocah) antara kepuasan pengguna dan kualitas informasi aset tetap, melainkan hanya hubungan satu arah dari kualitas informasi aset tetap terhadap kepuasan pengguna saja. Hasil penelitian ini tidak sesuai dengan penelitian Santoso (2012) dan Laksono (2015) yang menemukan bahwa kepuasan pengguna akan berpengaruh terhadap manfaat bersih yang diperoleh dari sistem informasi. Manfaat yang hendak diperoleh dari penggunaan SIMDA BMD adalah pengguna dapat menyajikan informasi aset tetap yang berkualitas untuk menyukseskan implementasi kebijakan restatement aset tetap kedalam neraca berbasis akrual. Hasil penelitian ini juga kontradiktif dengan hasil penelitian Darwanis dan Mahyani (2009) yang menemukan bahwa pemanfaatan sistem informasi akan mempengaruhi kepuasan pengguna yang pada akhirnya akan meningkatkan keterandalan pelaporan keuangan, serta tidak mendukung hasil dalam Penelitian Indriasari dan Nahartyo (2008) yang menemukan bahwa kapasitas sumber daya manusia yang mempengaruhi ketepat 
waktuan informasi. Namun di sisi lain, hasil penelitian ini mendukung penelitian Karmila et al. (2014) yang menemukan kapasitas SDM (pengguna) tidak berpengaruh dalam meningkatkan keterandalan informasi pelaporan keuangan.

Pada penelitian ini tidak ditemukan bukti kepuasan pengguna mempengaruhi kualitas informasi aset tetap yang dihasilkan (manfaat bersih). Kondisi di lapangan bisa jadi menjelaskan hal tersebut, yaitu ditemukan bahwa pengguna belum memiliki kompetensi yang memadai dalam pengoperasian SIMDA BMD, belum benar-benar memahami tentang penatausahaan aset tetap berdasarkan SAP berbasis akrual, serta masih kurangnya sosialisasi mengenai kegiatan restatement aset tetap pada neraca berbasis akrual. Berbagai macam alasan tersebut memposisikan pengguna hanya sebagai operator SIMDA BMD saja, yang tugasnya meng-input-kan data aset yang diperoleh dari Kasubag Umum dengan tujuan menyelesaikan pekerjaan sebagai beban kerja yang diberikan. Pengguna belum memahami kemana arah dan tujuan kegiatan penatausahaan aset tetap yang dilakukan, serta sejauh mana pengguna dapat mempengruhi hasil kualitas informasi aset tetap yang akan dihasilkan berdasarkan kinerja yang dilakukan.

Hasil pengujian hipotesis 4a menunjukkan bahwa terdapat pengaruh positif pengendalian organisasi terhadap kualitas informasi aset tetap yag dihasilkan. Dari tabel 3 diketahui bahwa pengendalian organisasi berpengaruh positif dan signifikan terhadap kualitas informasi aset tetap, dengan kata lain semakin meningkat pengendalian organisasi yang diberikan maka kualitas informasi aset tetap juga akan meningkat. Berdasarkan hasil pengujian diketahui bahwa hipotesis $4 \mathrm{~b}$ menyatakan bahwa terdapat pengaruh kualitas informasi aset tetap terhadap pengendalian organisasi. Dari tabel 3 diketahui bahwa kualitas informasi aset tetap berpengaruh positif dan signifikan terhadap pengendalian organisasi, dengan kata lain semakin meningkat kualitas informasi aset tetap maka pengendalian organisasi yang diberikan juga akan meningkat.

Hasil penelitian ini menunjukkan terdapat hubungan timbal balik (reciproca) antara pengendalian organisasi dan kualitas informasi aset tetap. Hasil penelitian ini sesuai dengan Nasyir dan Syaputra (2014) dalam penelitiannya yang menemukan bahwa variabel organisasi mempengaruhi manfaat bersih yang akan diperoleh dari penerapan sistem. Hasil ini juga sejalan dengan penelitian Poluan et al. (2014) yang menemukan bahwa net benefit yang diperoleh dari sistem yang digunakan rendah jika pengaruh organisasi yang diberikan rendah. Di sisi lain, hasil penelitian ini kontradiktif dengan hasil penelitian Karmila et al. (2014) yang justru menemukan bahwa pengendalian internal akuntansi tidak mempengaruhi kualitas informasi dalam laporan keuangan.

Hasil penelitian ini menguatkan bahwa pengendalian internal pada masing-masing SKPD akan berpengaruh pada kualitas informasi aset tetap yang dihasilkan. Apabila pengendalian internal yang diberikan semakin bagus maka kualitas informasi yang dihasilkan juga semakin baik, begitu juga jika pengendalian internal yang diberikan buruk maka kualitas informasi yang dihasilkan juga akan buruk. Di sisi lain, kualitas informasi yang baik akan meningkatkan pengendalian yang diberikan, karena dengen meningkatnya kualitas informasi yang dihasilkan, maka opini WTP yang telah diraih Pemkot Mataram akan dapat dipertahankan sehingga semakin banyak anggaran yang dapat digunakan untuk melakukan program peningkatan pengendalian agar penatausahaan aset tetap dapat dilakukan dengan lebih baik lagi.

\section{SIMPULAN}

Penelitian ini bertujuan untuk menguji determinan kualitas informasi aset tetap pada neraca berbasis akrual menggunakan pendekatan HOT-Fit Framework dan metode analisis Generalized Structural Component Analysis (GeSCA). Pengujian dilakukan pada 90 responden yang mewakili seluruh Satuan Kerja Perangkat Daerah (SKPD) pada Pemerintah Kota (Pemkot) Mataram dengan menggunakan kuesioner. Kelompok responden adalah pengurus barang (operator SIMDA BMD), admin SIMDA BMD, serta pejabat penatausahaan aset yang berwenang pada Pemkot Mataram dengan menggunakan analisis model struktural.

Hasil penelitian menunjukkan bahwa terdapat hubungan timbal balik (reciprocal) antara pengendalian organisasi dan kualitas informasi aset tetap. Hal ini mendukung argumen mengenai pentingnya peran pihak pengendali internal pada masing-masing SKPD dalam menentukan kualitas informasi aset tetap yang dihasilkan. Peningkatan pengendalian organisasi yang diberikan merupakan salah satu kunci penting agar dapat meningkatkan kualitas informasi aset tetap yang dihasilkan. Kualitas informasi aset tetap yang telah dihasilkan juga harus selalu dievaluasi dan menjadi masukan bagi pengendali organisasi agar dapat menyesuaikan manajemen strategik yang akan dirumuskan, dalam rangka meningkatkan atau minimal mempertahankan kualitas yang telah dicapai.

Lebih lanjut, pada penelitian ini ditemukan bukti empiris bahwa pada penatausahaan aset tetap lingkup Pemkot Mataram tidak terdapat hubungan timbal balik (reciproca) antara kepuasan pengguna dan kualitas informasi aset tetap. Hanya terdapat pe- 
ngaruh satu arah antara kualitas informasi aset tetap terhadap kepuasan pengguna. Hal ini menunjukkan kepuasan pengguna SIMDA BMD tidak mempengaruhi kegiatan penatausahaan aset yang dilakukan pengguna, dalam kontribusinya untuk meningkatkan kualitas informasi aset tetap, tetapi di sisi lain tingkat kualitas informasi aset tetap yang dihasilkan akan mempengaruhi kepuasan pengguna SIMDA BMD.

Keterbatasan dalam penelitian ini akan memberi arah bagi penelitian mendatang. Pertama, penelitian ini mengukur manfaat bersih (net benefit) dari penggunaan SIMDA BMD hanya dari manfaat informasional yang diperoleh organisasi. Untuk penelitian selanjutnya, manfaat bersih dapat diperluas pengukurannya dengan manfaat stratejik yang diperoleh organisasi, seperti manfaat keuntungan kompetitif (competitive advantage benefit) atau manfaat hubungan-pelanggan (customer-relation benefit) yang pada sektor publik akan dilihat sebagai manfaat hubunganstake-holders. Kedua, pada penelitian selanjutnya perlu dikembangkan jenis penelitian campuran ( $m i x$ method), yaitu mempertemukan atau menyatukan data kuantitatif dan data kualitatif untuk memperoleh analisis komprehensif atas masalah penelitian (Creswell, 2010). Hal ini dilakukan untuk lebih memahami mengapa sistem berfungsi dengan baik atau buruk dalam pengaturan tertentu.

\section{LAMPIRAN}

\section{Pengukuran Variabel}

Kualitas Software SIMDA BMD (KS), yang direfleksikan dengan indikator:

$\mathrm{X}_{1.1}=$ Mudah dipelajari; $\mathrm{X}_{1.2}=$ Mudah dioperasikan; $\mathrm{X}_{1.3}=$ Efisiensi loading; $\mathrm{X}_{1.4}=$ Efisiensi penyelesaian laporan; $\mathrm{X}_{1.5}=$ Bebas error; $\mathrm{X}_{1.6}=$ fasilitas bantuan teknis; $\mathrm{X}_{1.7}=$ Fitur entry data user friendly, $\mathrm{X}_{1.8}=$ Fitur edit data user friendly, $\mathrm{X}_{1.9}=$ Fitur back up dan restore data user friendly; $\mathrm{X}_{1.10}=$ Fitur browse praktis

Kepuasan Pengguna (KP), direfleksikan dengan indikator:

$\mathrm{Y}_{1.1}=$ Persepsi terbantu; $\mathbf{Y}_{1.2}=$ Peningkatan produktifitas; $\mathrm{Y}_{1.3}=$ Mempermudah pekerjaan; $\mathbf{Y}_{1.4}=$ Kenyamanan; $\mathbf{Y}_{1.5}=$ Ketergantungan; $\mathbf{Y}_{1.6}=$ Kepercayaan; $\mathrm{Y}_{2.1}=$ Fitur entry data praktis digunakan; $\mathrm{Y}_{2.2}=$ Fitur edit data praktis digunakan; $\mathbf{Y}_{2.3}=$ Fitur browse mudah; $\mathbf{Y}_{2.4}=$ Fasilitas sistem memenuhi kebutuhan; $\mathrm{Y}_{2.5}=$ Tampilan informasi sesuai kebutuhan; $\mathbf{Y}_{2.6}=$ Bentuk informasi sesuai kebutuhan; $\mathbf{Y}_{2.7}=$
Membantu pengambilan keputusan; $\mathrm{Y}_{2.8}=$ Menjadi dasar pengambilan keputusan

Pengendalian Organisasi (PO), direfleksikan dengan indikator:

$\mathbf{Y}_{3.1}=$ Update aplikasi; $\mathbf{Y}_{3.2}=$ Ada pedoman pengoperasian; $\mathbf{Y}_{3.3}=$ Pengaturan otoritas user menu; $\mathbf{Y}_{3.4}=$ Jaminan keamanan data; $\mathbf{Y}_{3.5}=$ Adanya layanan konsultasi; $\mathbf{Y}_{3.6}=$ Adanya layanan pengaduan; $\mathrm{Y}_{3.7}=$ Evaluasi Permasalahan; $\mathbf{Y}_{3.8}=$ Pelayanan responsif; $\mathbf{Y}_{3.9}=$ Dukungan Teknis; $\mathrm{Y}_{3.10}=$ Teknisi sesuai kebutuhan; $\mathrm{Y}_{4.1}=$ Dilakukan pelatihan SIMDA BMD; $\quad \mathbf{Y}_{4.2}=$ Sosialisasi restatement aset tetap pada neraca akrual; $\mathbf{Y}_{4.3}=$ Kepatuhan pada regulasi; $\mathrm{Y}_{4.4}=$ Dukungan pimpinan; $\mathbf{Y}_{4.5}=$ Pengarahan dari pimpinan; $\mathbf{Y}_{4.6}=$ Program khusus penatausahaan aset tetap; $\mathrm{Y}_{4.7}=$ Kesesuaian reward; $\mathbf{Y}_{4.8}=$ Sanksi pelanggaran secara internal; $\mathbf{Y}_{4.9}=$ Sanksi pelanggaran dari BPKAD; $\mathrm{Y}_{4.10}=$ Evaluasi penerapan kebijakan

Kualitas Informasi Aset Tetap (KIAT), direfleksikan dengan indikator:

$\mathbf{Y}_{6.1}=$ Manfaat umpan balik; $\mathbf{Y}_{6.2}=$ Manfaat Prediktif; $\mathbf{Y}_{6.3}=$ Tepat Waktu; $\mathbf{Y}_{6.4}=$ Lengkap; $\mathbf{Y}_{7.1}$ $=$ Informasi kondisi aset sesuai kondisi fisik; $\mathbf{Y}_{7.2}$ $=$ Informasi pemanfaatan aset akurat; $\mathbf{Y}_{7.3}=$ Dapat diverifikasi; $\mathbf{Y}_{7.4}=$ Netralitas; $\mathbf{Y}_{8.1}=$ Perbandingan antar periode; dan $\mathrm{Y}_{8.2}=$ Perbaikan informasi dengan kebijakan baru; $\mathbf{Y}_{9.1}=$ Pengungkapan dan $\mathbf{Y}_{9.2}=$ Bentuk sesuai regulasi

\section{DAFTAR PUSTAKA}

Arifin, J. F. dan S. Pratolo. 2012. Pengaruh Kualitas Sistem Informasi Keuangan Daerah Terhadap Kepuasan Aparatur Pemerintah Daerah Menggunakan Model Delone dan Mclean. Jurnal Akuntansi dan Investasi, 13 (1). 28-34.

Atikah, S., S. Am dan A. H. Lestari. 2015. Penerapan Prinsip - Prinsip Good Governance dalam Pengelolaan Barang Milik Daerah (Studi Pada Pemerintah Daerah Kota Mataram). Paper Dipresentasikan pada Konfrensi Regional Akuntansi II, Malang.

Badan Pemeriksa Keuangan Republik Indonesia. 2014. Ikhtisar Hasil Pemeriksaan Semester I Tahun 2014, Buku II Pemeriksaan Laporan Keuangan. Badan Pemeriksa Keuangan Republik Indonesia. Jakarta.

Bahrawi. 2013. Evaluasi Sistem Informasi Portal Intranet (Studi Kasus: Portal Intranet Kementerian Komunikasi dan Informatika). Paper Dipresentasikan pada Temu Ilmiah Jurnal Evaluasi, Yogyakarta. 
Bastian, I. 2011. Sistem Akuntansi Sektor Publik. Edisi 2. Salemba Empat. Jakarta.

Creswell, J. W. 2010. Research Design Pendekatan Kualitatif, Kuantitatif, dan Mixed. Edisi Ketiga. Yogyakarta: Pustaka Pelajar.

Darwanis dan D. D. Mahyani. 2009. Pengaruh Kapasitas Sumber Daya Manusia, Pemanfaatan Tehnologi Informasi dan Pengendalian Intern Akuntansi Terhadap Keterandalan Pelaporan Keuangan Pemerintah Daerah. Jurnal Telaah \& Riset Akuntansi, 2 (2), 133151.

Diana, K. 2014. Evaluasi Penerimaan Kinerja Human Resource Information System Universitas Bina Darma. Jurnal Matriks, 16 (2).

DeLone, W. H. dan E. R. McLean. 1992. Information System Success: The Quest for the Dependent Variable. Infomation System Research, 3 (1), 60-95.

DeLone, W. H. dan E. R. McLean. 2003. The DeLone and McLean Model of Information System Success: A ten-Year Update. Journal of Management Information Systems, 19 (4), 930.

DeLone, W. H. 2009. The Determinants of Information Systems Success. Paper Dipresentasikan pada Seminar di Kogod School of Business, American Univer-sity.

Indriasari, D. dan E. Nahartyo. 2008. Pengaruh Kapasitas Sumber Daya Manusia, Pemanfaatan Teknologi Informasi, dan Pengendalian Intern Akuntansi Terhadap Nilai Informasi Pelaporan Keuangan Pemerintah Daerah. Paper Dipresentasikan pada Simposium Nasional Akuntansi XI, Pontianak.

Istianingsih dan W. Utami. 2009. Pengaruh Kepuasan Pengguna Sistem Informasi Terhadap Kinerja Individu (Studi Empiris Pada Pengguna Paket Program. Aplikasi Sistem Informasi Akuntansi Di Indonesia). Paper Dipresentasikan pada Simposium Nasional Akuntansi XII, Palembang.

Karmila, T., A. R. Darlis dan Edfan. 2014. Pengaruh Kapasitas Sumber Daya Manusia, Pemanfaatan Teknologi Informasi, dan Pengendalian Intern Terhadap Keterandalan Pelaporan Keuangan Pemrintah Daerah (Studi Pada Pemerintah Provinsi Riau). Jurnal SOROT, 9 (1), 25-42.

Komara, A. 2006. Analisis Faktor-Faktor Yang Mempengaruhi Kinerja Sistem Informasi Akuntansi. Jurnal MAKSI, 6 (2), 143-160.

Krisbiantoro, D., M. Suyanto dan E. T. Luthfi. 2015. Evaluasi Keberhasilan Implementasi Sistem
Informasi dengan Pendekatan HOT Fit Model (Studi Kasus: Perpustakaan STMIK Amikom Purwokerto). Paper Dipresentasikan pada Konferensi Nasional Sistem \& Informatika 2015, STMIK STIKOM, Bali.

Laksono, H. 2015. Evaluasi Kesuksesan Sistem Informasi Manajemen Daerah-Barang Milik Daerah (SIMDA-BMD) Pada Pemerintah Kabupaten Klaten. Tesis, Universitas Gadjah Mada.

Mohamadali, N. A. K. dan J. M. Garibaldi. 2012. Understandingand Addressing The'Fit' Between User,Technologyand Organization In Evaluating User Acceptance of Healthcare Technology. Proceedings of the International Conference on Health Informatics (pp. 119124).

Nasir, M. dan H. Syaputra. 2014. Faktor-Faktor Pendukung Dalam Penerapan Sistem Paket Aplikasi Sekolah Pada Pendidikan SMA Negeri Di Palembang. Prosiding SNaPP2014 Sains, Teknologi, dan Kesehatan.

Nurdiana, S. R. 2015. Faktor-Faktor yang Mempengaruhi Optimalisasi Pemenfaatan Aset Tetap Pada Pemerintah Kota Mataram. Tesis, Universitas Mataram.

Padmowati, S. 2004. Implementasi Sistem Informasi Manajemen Daerah di Kabupaten Jepara. Tesis, Universitas Diponegoro.

Peraturan Daerah Kota Mataram No. 17 Tahun 2011 tentang Pengelolaan Barang Milik Daerah

Peraturan Menteri Dalam Negeri No. 17 Tahun 2007 tentang Pedoman Teknis Pegelolaan barang Milik Daerah.

Peraturan Menteri Dalam Negeri No. 64 Tahun 2013 tentang Penerapan SAP Berbasis Akrual pada Pemerintah Daerah

Peraturan Pemerintah No. 27 Tahun 2014 tentang Pengelolaan Barang Milik Negara/Daerah.

Peraturan Pemerintah No. 71 Tahun 2010 tentang Standar Akuntansi Pemerintah

Peraturan Walikota No. 13 Tahun 2014 tentang Kebijakan Akuntansi Pemerintah Kota Mataram

Poluan, F., A. Lumenta dan A. Sinsuw. 2014. Evaluasi Implementasi Sistem E-Learning Menggunakan Model Evaluasi Hot Fit Studi Kasus Universitas Sam Ratulangi. E-journal Teknik Informatika, 4 (2), 2301-8364

Putra, W. M., dan M. Alfian. 2016. Pengujian Kesuksesan Implementasi Sistem Informasi Akuntansi Lembaga Keuangan Mikro: Modified Delone Mcleon Model. Jurnal Akuntansi dan Investasi, 17 (1), 53-65. 
Santoso, H. 2012. Kajian Efektivitas Sistem Informasi Pangkalpinang Education Cyber City (PECC) Berdasarkan Pendekatan Model Delone dan Mclean: Studi Kasus Dinas Pendidikan Kota Pangkal pinang. (http://jurnal.atmaluhur.ac.id/)

Sofyani, H., dan R. Akbar. 2013. Hubungan Faktor Internal Institusi Dan Implementasi Sistem Akuntabilitas Kinerja Instansi Pemerintah (SAKIP) di Pemerintah Daerah. Jurnal Akuntansi dan Keuangan Indonesia, 10 (2), 184-205.

Sofyani, H., dan R. Akbar. 2015. Hubungan Karakteristik Pegawai Pemerintah Daerah dan Implementasi Sistem Pengukuran Kinerja: Perspektif Isomorfisma Institusional. Jurnal Akuntansi \& Auditing Indonesia, 19 (2), 153173.

Sudarmadi. 2010. Faktor-faktor yang Mempengaruhi Kepuasan Pengguna Sistem Informasi (Studi pada Aparat Pemerintah Daerah Kabupaten Sragen). Tesis, Universitas Sebelas Maret.

Surastiani, D. P. Dan B. D. Handayani. 2015. Analisis Faktor-Faktor Yang Mempengaruhi Kualitas Informasi Laporan Keuangan Pemerintah Daerah. Jurnal Dinamika Akuntansi, 7 (2), 139-149.

Yusof, M. M., R. J. Paul dan L. K. Stergioulas. 2006. Towards a Framework for Health Information Systems Evaluation. Proceedings of the 39th Hawaii International Conference on System Sciences - 20060-7695-2507-5/06/\$20.00 (C) 2006 IEEE

Yusof, M. M., Kuljis, J., Papazafeiropoulou, A., Stergioulas, L. K. 2008. An Evaluation Framework For Health Information Systems: Human, Organization, and Technology-Fit Factors (HOT-Fit). International Journal of Medical Informatics, 77 (6), 386-398.

Yusof, M. M. 2011. Hot-Fit Evaluation Framework: Validation Using Case Studies and Qualitative Sytemic Review in Health Information Systems Evaluation Adoption. Proocedings of $5^{\text {th }}$ EuropeConference on Information Management and Evaluation, 8-9 September, Mono: Italy.

Yusof, M. M. Dan Y. A. Y. Yusuff. 2013. Evaluating E-Government System Effectiveness Using an Integrated Socio-Technical and Fit Approach. Information Technology Journal, 12 (5), 894906. 